Article for Preprint

\title{
Humic Carbon to Fix Food, Climate and Health
}

\author{
Robert J. Blakemore ${ }^{1,2}$
}

1 VermEcology, 101 Suidomichi, Nogeyama, Yokohama-shi, Kanagawa-ken 231-0064, Japan; rob.blakemore@gmail.com

2 Kanagawa Prefectural Museum of Natural History, Odawara, Kanagawa-ken 247-0007

\begin{abstract}
Shutdown for just six days enables land plants to entirely fix $\mathrm{CO}_{2}$ excess of +4 Gt $\mathrm{C}$ per yr. Rebuilding soil organic carbon (SOC) in worm-worked humus is the only practical carbon capture and storage (CCS) capable of freely offsetting annual anthropogenic emissions. A case is made to redirect all available resources towards proven, earthworm-based, organic husbandry. Priority is to safely combat mounting global threats due to irreversible species extinction, perilous climate change and deteriorating human wellbeing (mental/physical health). All three interlinked risks are underpinned by a relentless, yet largely ignored, critical loss of precious topsoil. A first step to topsoil recovery is vermi-composting all vegetable and animal 'wastes' for return to the field.
\end{abstract}

Keywords: soil organic carbon sequestration, climate, organic agriculture, cancer, earthworm, fire.

\section{Introduction}

Climate change is mainly due to excess carbon accumulation in the atmosphere currently at a rate of $\left.+4 \mathrm{Gt} \mathrm{C} \mathrm{(+2} \mathrm{ppm} \mathrm{CO}_{2}\right)$ per year. This is not an economic, chemical, geo-physical nor an engineering problem, rather it is an ecological imbalance attributed to land clearance and burning combined with rate of fossil fuels emissions exceeding the living Earth's ability to reprocess. The UN's latest bulletin (IPCC 2018) predicts a brief window of just 12 years - to 2030 - in which to tackle the perils of climate change. Temporary shutdown, as partially imposed in the USA in 2018/2019, may provide $\mathrm{CO}_{2}$ respite measurable at Mauna Loa Observatory (Figure 1).

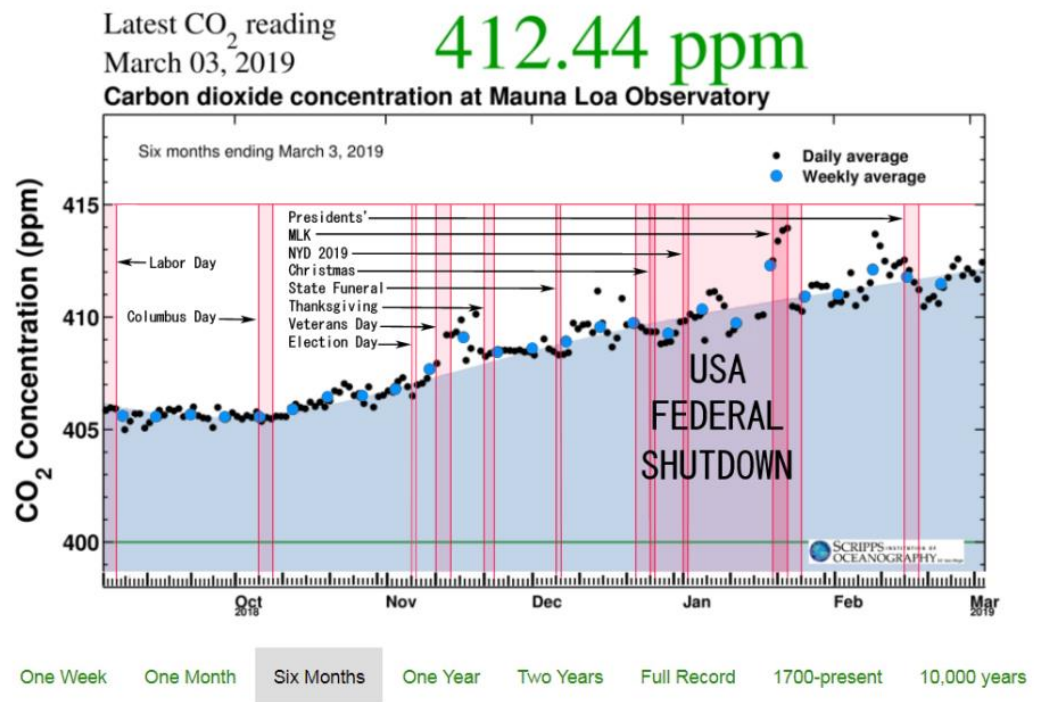

Figure 1. $\mathrm{CO}_{2}$ on Hawaii with US holidays and shutdown of 800,000 staff; notwithstanding seasonal/local weather, time lag or other confounding factors, slight correlation links to human activities may be detectable.

Climate is not the greatest threat, however, as both a loss of species diversity (due largely to "conversion of natural ecosystems into agriculture or into urban areas") and excess synthetic fertilizers were both flagged as more urgent by Rockström et al. (2009). Most their nine pillars for survival rely entirely upon topsoil that, based upon UN's FAO data, provides $99.7 \%$ of human food (just $0.3 \%$ from 
fisheries) whilst also being increasingly lost at a rate of 2,000 tonnes per second (Pimental \& Burgess 2013, Blakemore 2018b). Of the top 100 climate remedies from the Drawdown project (https://www.drawdown.org/), about 85 of their suggestions are based on adaptable Permaculture principles and practices (Mollison 1988) that essentially condense to one: simply saving our soils.

Critical and rapid loss of soil invertebrates (insects and earthworms) and collapse of other organism food-web diversity by $-50-100 \%$ is attributed partly to climate warming but mainly to agrichemical intensification (Carson 1963, Blakemore 2018a, Bradfield \& Garcia 2018) (Figure 2).

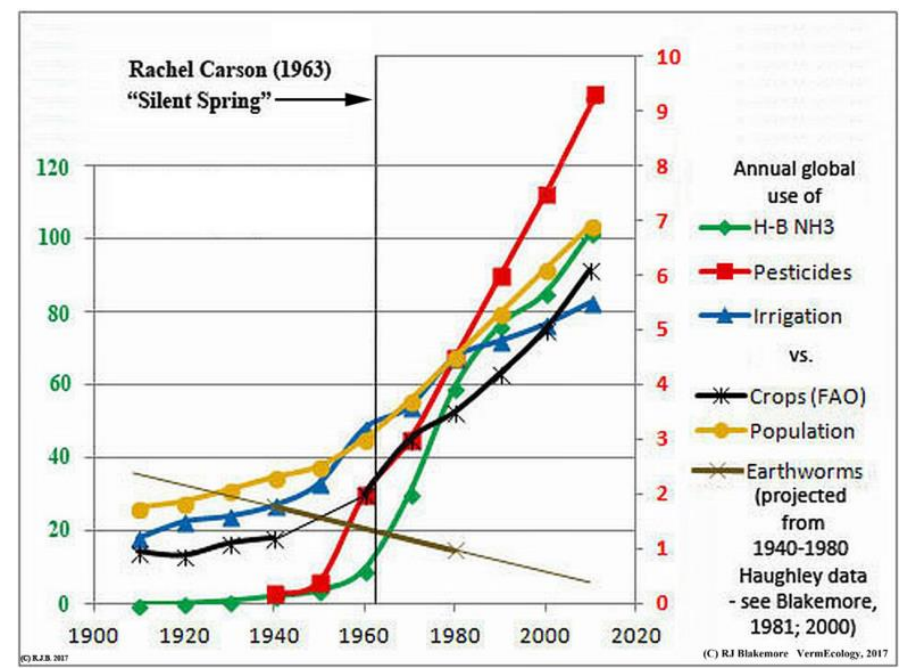

Figure 2. Agrichemical use and population rise (yellow, due partly to education on hygiene), with earthworm decline (brown). FAO's commercial crops (black, omitting smaller family farms with higher yields per area and in total) correlate more with irrigation (blue) than fertilizers (green) or biocides (red, that yet increase exponentially despite Rachel Carson's 1963 "Silent Spring" warning). (From https://vermecology.wordpress.com/2017/05/27/slimeless-spring-ii/).

Toxic agrichemicals are known to cause allergies, cancer, neurological and reproductive problems in test cells, in animals and in humans (Carson 1963). Farm workers and children are particularly susceptible with induced cancer, Parkinson's and autism rates higher and linked to some of the 80,000 synthetic chemical mixtures in circulation. For example, the most ubiquitous herbicide, glyphosate (as used in "no-till"), is associated with cancer and other ecological problems (Seralini 2012, 2014, Swanson et al. 2014, Leon et al. 2019, Zhang et al. 2019, Gaup-Berghausen et al. 2015). Patented as a chelating pipe-cleaner and a broad antibiotic (US Pat. 7771736) its targets include beneficial soil algae and N-fixing bacteria (Pseudomonadaceae eg Azomonas or Azotobacter) and symbiotic Enterobacteriaceae in gut flora of humans, ruminants, honey bees and earthworms.

Ecologically, all three of these problems (biodiversity, climate and health) are interlinked and solvable by the simple expedient of restoring organic farming, as advocated by Howard (1945) and Balfour (1975) from the time of agricultural intensification spread following WW2. The mantra that chemical agriculture is required to "feed the world" and to provide " $70 \%$ more food by 2050 " is demythified (UN-HRC 2017 and as discussed below) by FAO data showing 80\% of sustenance already comes from small family farms (not from destructive and highly subsidized GMO canola, corn or soy monoculture) and that a predicted population increase of $20 \%$ requires just $20 \%$ more food if excessive meat eating is moderated. Organic farming preserves or restores biodiversity, conserves soil organic matter $(+50 \%)$ and essential soil moisture $(+25 \%)$ whilst also saving costs plus providing greater employment and healthy food without overall loss of production (FAO 2017, Blakemore 2015a,b, 2018a).

The idea that atmospheric carbon increase may be related to loss of soil is not new: A paper by Revelle \& Suess (1957) proposed it as one possible cause of Callendar's effect. A global carbon debt due to agriculture is now thought to be of $\sim 133-150 \mathrm{Gt} C$ for the top $2 \mathrm{~m}$ of soil, with the rate of loss increasing dramatically in the past 200 years (Batjes 2018, Sanderman et al. 2017). Australia has been particularly affected, and global decreases in soil organic carbon (SOC) stocks of $-40-60 \%$ from pre- 
clearing levels have caused emissions of at least $150 \mathrm{Gt}$ of carbon dioxide into the atmosphere $(=41$ $\mathrm{Gt}$ C) and approximately $78 \mathrm{Gt} C$ lost from the global soil pool due to agricultural land-use conversion with 26 Gt due to erosion and 52 Gt to mineralization (CSIRO 2010). Köhl et al. (2015) show largest loss of carbon estimated at about $5 \mathrm{Gt} C$ from forest soils just from 1990-2015. Blakemore (2018a) plots SOC lost from the earliest non-organic fields of $-60 \%$ during the last $175 \mathrm{yrs}$.

Yet it was only in 2015 that the international "4 per 1,000 Initiative" (4p1000.org) proposed increasing soil carbon by $0.4 \%$ from a supposed starting base of $1,500 \mathrm{Gt} \mathrm{SOC}$. This total is now raised to $>8,500$ Gt due to terrain (but with about 3,400 Gt in permafrost) (Blakemore 2018b), thus only 0.1$0.2 \%$ extra $C$ is now required. Conserving a living and vibrant topsoil is an implicit aim of both original organic farming and of Permaculture that, practiced at local or broadacre scale, have potential to entirely offset excess carbon associated with climate change (Blakemore $2015 \mathrm{a}, \mathrm{b}$ ).

This paper further investigates how organic farming may redress these most urgent issues.

\section{Materials and Methods}

Published reports based upon NASA, NOAA, 4p1000 and UN's IPCC data are reviewed and revised for newly recalibrated land surface areas (Blakemore 2018b). The photosynthesis formula $6 \mathrm{CO}_{2}+6 \mathrm{H}_{2} \mathrm{O}+$ light energy $=\mathrm{C}_{6} \mathrm{H}_{12} \mathrm{O}_{6}+6 \mathrm{O}_{2}$ is reversed by respiration and decomposition (mainly by microbes and earthworms), both being forms of slow combustion, with equation $\mathrm{C}_{6} \mathrm{H}_{12} \mathrm{O}_{6}+6 \mathrm{O}_{2}=$ $6 \mathrm{CO}_{2}+6 \mathrm{H}_{2} \mathrm{O}$ (carbohydrate + oxygen $\rightarrow$ carbon dioxide + water). Photosynthesis operates within temperature constraints and requires chlorophyll. Production is mainly terrestrial by autotrophic vascular plants plus cryptogamic mosses or lichens and biocrust (including land-based microbial "phytomenon" as opposed to phytoplankton as is discussed in an attached supplementary data file).

Values are herein measured as total carbon rather than $\mathrm{CO}_{2}$ and rates are in $\mathrm{GtC} / \mathrm{yr}\left(=\mathrm{PgC} \mathrm{yr}{ }^{-1}\right)$.

\section{Results and Discussion}

\subsection{Shutdown}

Possibility of remission is provided for by NASA (2011) and IPCC (2013: fig. 6.1) data with gross terrestrial photosynthesis of $123 \mathrm{Gt} C$ and $+4 \mathrm{Gt} C$ added to the atmosphere annually; thus $123 / 365=$ $0.33 \mathrm{Gt}$ C/day biofixed, i.e., just 12 days of natural land production accounts for the excess (viz. 0.33 Gt C/day x 12 days = 4 Gt C). When terrain allowance (Blakemore 2018b: tab. 11) doubles photosynthesis to at least $218 \mathrm{Gt} \mathrm{C/yr}$, but plausibly to $>250 \mathrm{Gt} \mathrm{C/yr}$, then this rate is newly reduced by about half. Therefore, just six days respite would be required to offset emissions in a temporary shutdown of non-essential business and transport synchronized perhaps for three days at each equinox or for one whole week (as for Japan's "Golden Week") at Vesak or around Rachel Carson's birthday in May corresponding to the northern hemisphere's $\mathrm{CO}_{2}$ peak. Aiming to readily offset annual excess atmospheric carbon accumulation assumes that it is truly of anthropogenic origin.

Given that human emissions are $\sim 9 \mathrm{Gt}$ and $\sim 4 \mathrm{Gt}$ is added to the atmosphere and $\sim 2 \mathrm{Gt}$ to the ocean, both NASA (2011) and IPCC (2013) balance a variable net terrestrial sink of around $\sim 3-4 \mathrm{Gt} / \mathrm{yr}$ (Figure 3). However, NASA separates land respiration vs. decomposition as $60 \mathrm{Gt}$ each $(123-120=3)$, whereas IPCC has "Total respiration and fire" discrepancy of $118.7 \mathrm{Gt} C(123-118.7=4.3)$. A passive airsea gas exchange makes marine photosynthesis relatively minor, limited by water soluble $\mathrm{CO}_{2}$ and by temperature, photons and nutrients - indeed, IPCC (2013: fig. 6.1) shows just 3 Gt total marine biota (cf. 450-650 Gt on land, this biomass total now quadrupled to above 2,000 Gt C - see Blakemore 2018b: tab. 10). Oceans are hereafter largely irrelevant for further practical carbon consideration as the net $\sim 2 \mathrm{Gt} C / \mathrm{yr}$ absorbed is less than $1 \%$ of the total annual air-land exchange. 


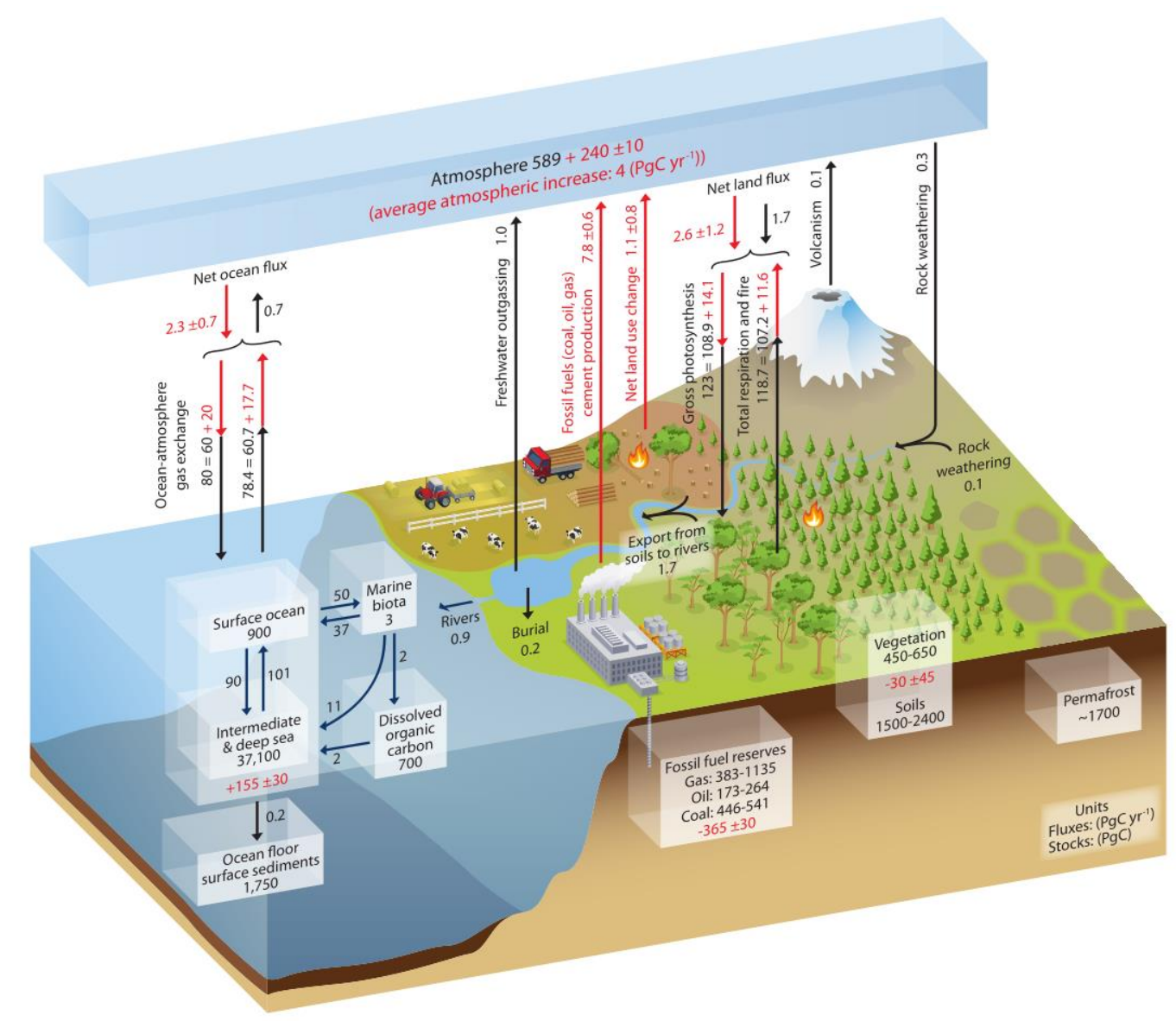

Figure 6.1 | Simplified schematic of the global carbon cycle. Numbers represent reservoir mass, also called 'carbon stocks' in $\mathrm{PgC}\left(1 \mathrm{PgC}=10^{15} \mathrm{gC}\right)$ and annual carbon exchange

Figure 3. IPCC (2013: fig. 6.1 https://www.ipcc.ch/report/ar5/wg1/) global carbon cycle with land sink of 1.4-3.8 Gt C/yr (cf. NASA 2011 has $3 \mathrm{Gt}$ ), this may increase with proper organic management and less fire. Note: IPCC allows 1,500-2,400 Gt C in soil and $1,700 \mathrm{Gt}$ in permafrost (max total 4,100 Gt) while Köchy et al. (2015: 361) have about 1,700 Gt in permafrost and 1,300 Gt elsewhere to total about 3,000 Gt SOC. This value was used by Blakemore (2018b) to arrive at a new accounting for terrain and topsoil to give 8,580 Gt SOC (i.e., with $\sim 1,700$ x $2=3,400$ in permafrost, cf. Schuur et al. 2015 - https://www.nature.com/articles/nature14338).

NASA/IPCC's human contributions of $+9 \mathrm{Gt} \mathrm{C} / \mathrm{yr}$ are $<4 \%$ compared to a revised natural flux of $>218 \mathrm{Gt} \mathrm{C} / \mathrm{yr}$ (>96\%) air-land (Blakemore 2018b: tab. 11) indicating not just excess emissions, but also a deficit of photosynthesis and/or a surfeit of respiration/decomposition/combustion. The entire 800 Gt of atmospheric carbon is recycled via plant litter through the intestines of earthworms and by microbial decomposition (Darwin 1881). Annual leaf-litter of $60 \mathrm{Gt} \mathrm{C}$, when terrain is considered (Blakemore 2018b), is approximately doubled ( 120 Gt C/yr) thus the carbon-cycle rate of $\sim 12$ years is halved (800/120) to $\sim 6.6$ years for worm-processing of all atmospheric carbon. Upped belowground microbial decomposition may further halve this rate and, logically, if $>218$ Gt of carbon from $800 \mathrm{Gt}$ in the atmosphere is photosynthesized each year then it would presumably take (800/218) 3.6 years at most for complete carbon recycling. Such values are supported by relatively rapid decline of radioactive ${ }^{14} \mathrm{C}$ isotope from atmospheric nuclear testing.

The current findings of $9 \mathrm{Gt}$ or $<4 \%$ human atmospheric emissions and $\sim 3.6$ yrs residence time, with different reasoning, seemingly support Harde (2017) who summarized: "The anthropogenic contribution to the actual $\mathrm{CO} 2$ concentration is found to be $4.3 \%$, its fraction to the $\mathrm{CO} 2$ increase over the Industrial Era is 15\% and the average residence time 4 years." A rebuttal paper by Köhler et al. (2018) rejects many of Harde's calculations outright but accepts "reasonable approximations for the residence time". If so, then $800 \mathrm{Gt}$ atmospheric $C$ recycled in $\sim 4$ yrs $(=800 \mathrm{Gt} / 1,460$ days $=0.55 \mathrm{Gt} /$ day), thus excess of $4 \mathrm{Gt} C$ per year is produced - or leveled by reprieve - in just $(4 \mathrm{Gt} / 0.55 \mathrm{Gt} /$ day $=) \sim 7$ days. Q.E.D. Therefore the question is: If $\mathrm{CO}_{2}$ excess is from human activities can it be leveled in a week? 
Higher in the landed northern hemisphere, atmospheric $\mathrm{CO}_{2}$ peaks in May and at midnights. Annual progression relates to respiration and decomposition on land until Spring turning point in boreal taiga forests when temperatures rise above $10^{\circ} \mathrm{C}$ allowing photosynthetic compensation. Disregarding gas fluxes, the most massive and meaningful total $C$ sequestration is in soil humus.

\subsection{Carbon Sequestration in Humus of Organic Farms also Sustains Food Supply}

Agriculture uses fully $50 \%$ of habitable land with a quarter of this area cultivated for crops that supply $83 \%$ of human food, the rest being pasture for beef and dairy that provide an extra $17 \%$ of calories ( $<1 \%$ food is from the ocean!); forests $(37 \%)$, marginal scrub $(11 \%)$ and cities $(2 \%)$ occupy the remaining liveable surface areas (Blakemore 2018b: fig. 4 from OurWorldinData data).

When trees are cleared, pastures ploughed, and plants or soils sprayed with biocides then vital soil biota - microbes, fungi and earthworms that do most of the biological work - are destroyed and topsoil humus depleted requiring yet more synthetic chemicals to compensate. Poisoned soils, sick children, dead birds, rivers running brown with silt and the air filling with dust from exposed ground are key indicators of collapse. This route to desertification is exacerbated by last-resort grazing of cattle, sheep or goats before an inevitable/eventual land abandonment (Mollison 1988).

Food security is partly due to political inadequacies and partly due to waste, but the true situation is $70-80 \%$ of global food being provided not by industrial agriculture but by local smallholders and gardeners; so industrialized food provides only about $20-30 \%$ of the total (Alitieri 2008, FAO 2014, 2019). Claims of 70\% more industrial food needed by 2050 are debunked (FAO 2107; Blakemore 2018a supplementary file - https://archive.org/details/S1AppendixWormMSRJB).

Permaculture, with appropriate ecological production (organic agroecology), defrays accumulation of toxic, persistent and harmful agrichemicals/pharmaceuticals whilst rebuilding healthy soils without jeopardizing food security. Harmful synthetic N-P-K fertilizers are replaced with microbial/fungal mineralization from vermicomposting of all organic 'wastes'. Doubling of land surface area and of topsoil relief (Blakemore 2018b), as well extra soil carbon, seemingly doubles or quadruple natural nitrogen fixation of microbes well above Smil's (2000) C and N totals.

Even with enforced or regulated $\mathrm{C}$ and synthetic $\mathrm{N}$ emissions reduction, the prime imperative is to remove excess $\mathrm{CO}_{2}$ from the air and the only way to achieve this is via photosynthesis on land with storage in worm-worked humus. In order to process and store more carbon the requirement (from the photosynthesis equation above) is to increase scope and scale by keeping soil covered with green plants for more of the year (e.g. cover crops and "green curtains") plus recycling of all organic wastes that are currently burned/incinerated or dumped. Extra photosynthesis is from halting deforestation (e.g. for intensive GMO soy in Brazil or palm oil in southeast Asia used for cattle feed/biofuels as a senseless waste of land/energy) or from reforestation to reverse desertification.

Based upon assumption of initial 1,500-2,500 GtC SOC, a change by $4 \mathrm{p} 1000$ of just $0.4 \% \mathrm{yr}^{-1}$

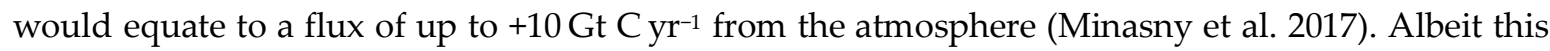
was disputed by Batjes (2018), his study did not include the new upwardly revised SOC totals $(8,580$ Gt) from Blakemore (2018b) that were accepted by Lal (201) and now requires just $0.1-0.2 \%$ extra SOC. Organic food production providing higher plant yields and greater carbon sequestration in humic topsoil $(+50 \%)$, has many other advantages compared to chemical farming in terms of lower water demands (+25\%), greater microbial activity and biodiversity (Blakemore 2015b; 2018a). Reduced pollution further reduces plant, animal and human ill-health (Balfour 1975).

\subsection{Biodiversity and Human Health}

The problems of chemical agricultural in critical species extinction, although topical, are not new and were reported almost 100 years ago from the earliest field experiments at Rothamsted (Morris $1922,1927)$ who found insects depleted by $-88 \%$ and earthworms almost completely eradicated at - 
99\% by synthetic chemical fertilizers (Blakemore 2018a: tab. 1; fig. 6). It is not just the soil invertebrates affected: birds and mammals including humans are also impacted (Carson 1963). Cancer rates from Carson of 1 in 4, are now $>1$ in 2 in US (https://www.cancer.gov/). According to their National Cancer Institute (https://seer.cancer.gov June, 2018) causes are just 5\% genetic, so $95 \%$ are due to chemical pollution and/or lifestyle resulting in the progressive banning of many farm chemicals. As noted, farm workers and children are particularly susceptible to "weed killers" with cancer, Parkinson's and autism rates particularly high and rising (Figure 4).

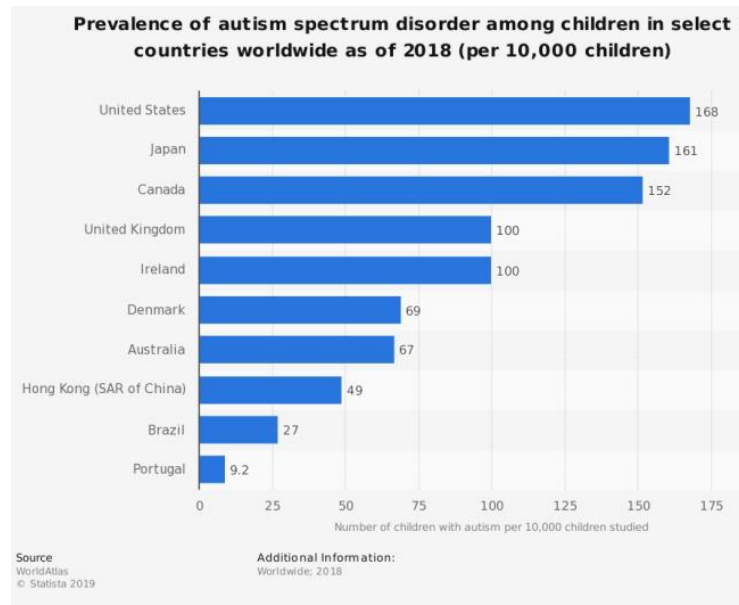

Thyroid Cancer Incidence Rate (age adjusted)

plotted against glyphosate applied to U.S. corn \& soy $(R=0.988, p<=7.612 \mathrm{e}-09)$ along with \%GE corn \& soy crops $R=0.9377, p<=2.152 e-05$

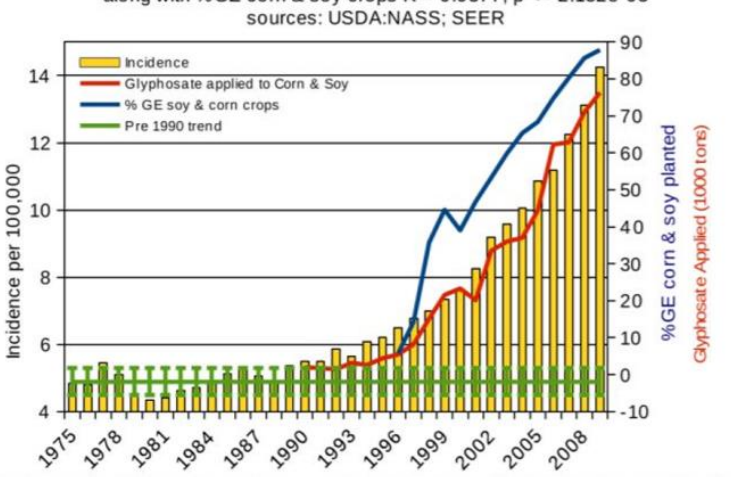

Figure 10. Correlation between age-adjusted thyroid cancer incidence and glyphosate applications and percentage of US corn and soy crops that are GE.

Figure 4. ASD in children in select countries in 2018 (WorldAtlas Statista); correlation of autism and other now common chronic diseases - e.g. diabetes, cancer, Alzheimer's, MS, IBS - with glyphosate use (Swanson et al. 2014: fig. 10; https://vermecology.wordpress.com/2018/05/27/wormageddon-destruction-in-our-soils/).

\subsection{Burning Issue}

Achieving 4p1000's extra 0.1-0.2\% SOC also implies reduction in all un-necessary burning. The FAO AFOLU (FAO 2014: 3) has the land use factor accounting for a third of total anthropogenic greenhouse gas forcing, this includes deliberate or proscribed fires in natural forest, savannah, moorland and peats with burning crop stubble, rice husks or sugarcane trash contributing to this. Forests may take 80-100 years to recover from logging or accidental fires (Bowd \& Lindemeyer 2019). Burning corresponds to areas of soil degradation (Figure 5).
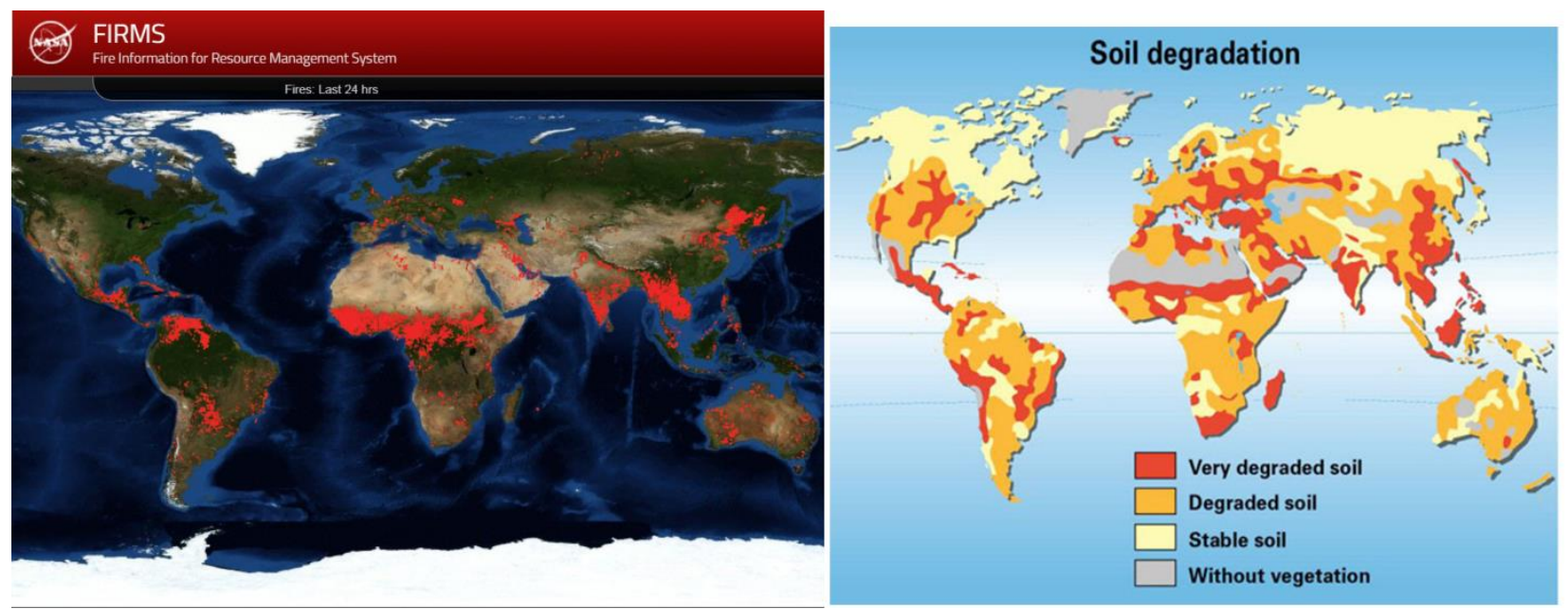

Figure 5. NASA's FIRMS real fire plots closely match UNEP's GRID-Arendal map of global soil degradation and desertification for which: "The primary causes are deforestation, overexploitation for fuelwood, overgrazing, agricultural activities and industrialization" (www.grida.no/resources/5507). 
In general, $\mathrm{CO}_{2}$ released by burning vegetation (about $1.9 \mathrm{~kg}$ per $\mathrm{kg}$ burnt due to $\mathrm{O}_{2}$ oxidation) is not included because, IPCC considers it balanced by carbon taken up during plant growth and the emissions as carbon "neutral" (e.g. IPCC 2014). If so, this is mistaken in my view as all plants can be mulched and their carbon returned to the soil as compost rather than adding yet more smoke into the atmosphere. This humic SOC aspect is perhaps an important yet undervalued consideration.

\section{Conclusions and Summary}

A planned annual shutdown for one week would offset $100 \%$ of annual $\mathrm{CO}_{2}$ accumulation and allow natural processes to progress, aided by programmes to help farmers transition to organic. An official view, however, is that Natural Climate Solutions (NCS) can provide only about one third of cost-effective climate mitigation alongside aggressive fossil fuel emission reductions (Griscom et al. 2017 study based upon IPCC 2014 - Working Group III, WGIII). Yet the subsequent 4p1000 (4p1000.org) organic humus plan - herein newly revised - provides a more feasible method. An unresolved issue is the contribution of permafrost that was factored in total SOC estimated by IPCC (2014) and Köcky et al (2015) as 1,700 total (see Figure 3 above) which may, however, be doubled by terrain to $\sim 3,400$ thus representing $25-50 \%$ of total global SOC at especial risk from warming.

Aside from carbon reduction in order to reduce a warming climate, the imperative is to remove toxic agrichemicals from the environment as an urgent priority to conserve biodiversity and to protect plant, animal and human well-being. The most practical means is by organic production that interlinks under the Permaculture umbrella with mutually beneficial issues in energy, housing and transport themselves requiring separate study (some as in Project Drawdown noted above).

Urbanization is not such a major consideration per se as it affects only $1-2 \%$ of land surface; forests, fields and prairies are more important. But education of 50\% of Earth's population living in towns is for a better appreciation and delight of Nature amidst its rapid, almost irretrievable loss. Perhaps at shutdown city folk can visit local gardens or parks for 'forest bathing', relish a meat-free barbecue, hike or run cross-country with friends, contemplate just sitting under a tree or aim to plant one as cool shade or sustenance for contemporary travellers and for our descendents to enjoy.

Supplementary File: Provides background on nuclear $\mathrm{C}$ isotopes and tree rings in sequestration; the Deep Carbon project (<20 Gt C) is compared with surface biocrust ( $>20 \mathrm{Gt} \mathrm{C}$ ), CoML with CoSI (Blakemore 2012); total carbon storage potential and other relevant source data. Available online at www.mdpi.com/xxx/s1... pending.

Funding: This research received no external funding.

Acknowledgments: Thanks to editors and referees for comments and improvements on the manuscript.

Conflicts of Interest: The author has none except wholly unpaid association with 4p1000.org and UN's GSP.

\section{References}

1. Altieri, M.A. Small Farms as a Planetary Ecological Asset. Third World Network, Penang, Malaysia, 2008. Online - https://pdfs.semanticscholar.org/c7f5/8922bb9765dd94e8e3f67eb9550fbc22dc3d.pdf.

2. Balfour, E.B. The Living Soil and the Haughley Experiment. Faber \& Faber, London, U.K., 1975.

3. Batjes, N.H. Soil organic carbon sequestration. LDD 2018, 30, 1. https://doi.org/10.1002//dr.3209.

4. Blakemore, R.J. Call for a Census of Soil Invertebrates (CoSI). Zool. Middle East 2012, 58, 171-176. Online https://vermecology.wordpress.com/2017/04/30/census-of-soil-invertebrated-cosi/.

5. Blakemore, R.J. Veni, Vidi, Vermi... I. On the Contribution of Darwin's 'Humble Earthworm' to Soil Health. Veop 2015a, 2(1), 1-34. Online - http://orgprints.org/31188/3/VVV\%20part-I.pdf (accessed on 10 May 2018).

6. Blakemore, R.J. Veni, Vidi, Vermi... II. Veop 2015b, 2(2), 1-26. Online - http://orgprints.org/31189/.

7. Blakemore, R.J. Critical Decline of Earthworms. Soil Syst. 2018a, 2, 33.

8. Blakemore, R.J. Non-flat Earth Recalibrated for Terrain and Topsoil. Soil Syst. 2018b, 3, 64.

9. Bradfield, B.C., Garcia, A. Forest food-web. PNAS 2018 115, E10397-E10406.

10. Bowd, E., Lindemeyer, D. 2019. Forest soil needs decades or centuries to recover from fires and logging theconversation.com/forest-soil-needs-decades-or-centuries-to-recover-from-fires-and-logging-110171.

11. Carson, R. Silent Spring. Hauthton Mifflin, USA/Penguin Books with Hamish Hamilton, U.K., 1962/1963. 
12. CSIRO 2010. Soil Carbon Sequestration Potential: A review for Australian agriculture. www.mla.com.au/globalassets/mla-corporate/blocks/research-and-development/csiro-soil-c-review.pdf.

13. Darwin, C.R. The Formation of Vegetable Mould through the Action of Worms. Murray, London, 1881.

14. FAO AFOLU 2014. http://www.fao.org/docrep/019/i3671e/i3671e.pdf.

15. FAO 2014. http://www.fao.org/3/a-i4036e.pdf.

16. FAO 2017. http://www.fao.org/agroecology/database/detail/en/c/473075/.

17. FAO 2019. Smallholders and Family Farmers. Sustainabity Pathways. www.fao.org/fileadmin/templates/nr/sustainability pathways/docs/Factsheet SMALLHOLDERS.pdf.

18. Griscom, B. et al. Natural climate solutions. PNAS 2017 114, 44. www.pnas.org/content/114/44/11645.full.

19. Gaup-Berghausen,M. et al. Sci Rep 2015, 5, 12886. www.ncbi.nlm.nih.gov/pmc/articles/PMC4542661/.

20. Harde, H. Scrutinizing the carbon cycle and $\mathrm{CO}_{2}$ residence time. Glob. Planet. Change 2017, 152, 19-26.

21. Howard, A. An Agricultural Testament. Oxford, UK: Oxford University Press, U.K., 1945.

22. IPCC 2013. Climate Change: The Physical Science Basis. www.ipcc.ch/report/ar5/wg1/; www.ipcc.ch/site/assets/uploads/2018/02/WG1AR5 all final.pdf.

23. IPCC 2014. Working Group III (WGIII). http://orbit.dtu.dk/files/103008543/ipcc wg3 ar5 chapter11.pdf.

24. IPCC 2018. https://www.ipcc.ch/sr15/.

25. Köchy, M., Heiderer, R., Freibauer, A. Global distribution of soil organic carbon - Part 1. Soil 2015, 1, 351365. https://doi.org/10.5194/soil-1-351-2015.

26. Köhl, M. et al. Changes in forest production. FEM 2015, 352, 21-34. https://www.sciencedirect.com/science/article/pii/S037811271500314X.

27. Köhler, P. et al. Comment on paper by Harde. Glob. Planet. Change 2018, 154, 67-71.

28. Lal, R. Conceptual basis of managing soil carbon: Inspired by nature and driven by science. J Soil Water Conserv. 2019, 74(2), 29A-34A. http://www.jswconline.org/content/74/2/29A.full.pdf+html.

29. Leon M.E. et al. Pesticide use and risk of non-Hodgkin lymphoid. IJE 2019, dyz017, https://doi.org/10.1093/ije/dyz017.

30. Minasy, B. et al. Soil carbon 4 permille, Geoderma 2017, 292, 59-86. doi.org/10.1016/j.geoderma.2017.01.002.

31. Mollison, B. Permaculture: A Designers' Manual; Tagari Publications: Sisters Creek, Australia, 1988.

32. Morris, H.M. The insect and other invertebrate fauna at Rothamsted. Ann. Appl. Biol. 1922, 9, $282-305$.

33. Morris, H.M. Ibid. Part II. Ann. Appl. Biol. 1927, 14, 442-464.

34. NASA 2011. https://earthobservatory.nasa.gov/Features/CarbonCycle/ (accessed on 13 December 2018).

35. Pimentel, D.; Burgess, M. Soil erosion threatens food production. Agriculture 2013, 3, $443-463$. doi:10.3390/agriculture3030443.

36. Revelle, R., Suess, H.E. Carbon dioxide exchange between Atmosphere and Ocean. Tellus 1957, $9,1$. http://uscentrist.org/platform/positions/environment/context-environment/docs/Revelle-Suess1957.pdf.

37. Rockström, J. et al. A safe operating space for humanity. Nature 2009, 461, 472-475. doi:10.1038/461472a.

38. Sanderman, J. et al. Soil carbon debt of 12,000 years of human land use. PNAS 2017, 114(36). https://www.ncbi.nlm.nih.gov/pmc/articles/PMC5594668/.

39. Schuur E.A.G. et al. Permafrost. Nature 2015, 520, 171-179. https://www.nature.com/articles/nature14338.

40. Séralini G-E. et al. Long term toxicity of a Roundup herbicide and a Roundup-tolerant genetically modified maize. Food Chem. Toxicol. 2012, 50(11), 4221-4231. doi:10.1016/j.fct.2012.08.005.

41. Séralini G-E. et al. Republished study: long-term toxicity of a Roundup herbicide and a Roundup-tolerant genetically modified maize. Environ. Sci. Eur. 2014, 26(1), 14. doi:10.1186/s12302-014-0014-5.

42. Smil, V. Enriching the Earth. MIT Press, Cambridge, MA, USA, 2000.

43. Swanson, N.L., Leu, A., Abrahamson, J., Wallet, B. Genetically engineered crops, glyphosate and the deterioration of health in the USA. JOS 2014, 9(2), 6-37. http://www.organicsystems.org/journal/92/JOS Volume-9 Number-2 Nov 2014-Swanson-et-al.pdf.

44. UN-HRC 2017. UN Experts Denounce 'Myth' Pesticides Are Necessary to Feed the World https://documents-dds-ny.un.org/doc/UNDOC/GEN/G17/017/85/PDF/G1701785.pdf?OpenElement.

45. Zhang L. et al. Glyphosate-Based Herbicides and Risk for Non-Hodgkin Lymphoma. MUTREV 2019, 8261, 1-22. Online - https://www.sciencedirect.com/science/article/pii/S1383574218300887. 